\title{
PELATIHAN PENELITIAN RESEARCH AND DEVELOPMENT BAGI GURU SD NEGERI 1 ARCAWINANGUN BANYUMAS
}

\author{
Ana Andriani ${ }^{1}$, Ine Kusuma Aryani ${ }^{2}$, Tri Yuliansyah Bintaro ${ }^{3}$ \\ ${ }^{1)}$ Prodi PGSD, Fakultas Keguruan dan Ilmu Pendidikan Universitas Muhammadiyah Purwokerto \\ ${ }^{2,3)}$ Prodi PPKn; Fakultas Keguruan dan Ilmu Pendidikan Universitas Muhammadiyah Purwokerto \\ email ana.andriani@gmail.com ${ }^{1}$; inepascapendas@gmail.com², bintaro.pwt@gmail.com
}

\begin{abstract}
Abstrak
Kompetensi profesional terkait dengan kemampuan guru dalam menguasai materi dari bidang studi atau mata pelajaran yang menjadi kewenangannya secara luas dan mendalam. Kompetensi profesional juga mencakup penguasaan materi keilmuan, penguasaan kurikulum dan silabus, metode khusus pembelajaran bidang studi, dan wawasan etika serta pengembangan profesi. Kompetensi kepribadian dan sosial sangat erat berhubungan dengan kemampuan guru dalam berinteraksi dan berkomunikasi secara efektif dan efisien, baik dengan peserta didik, sesama guru, orang tua / wali peserta didik, dan masyarakat sekitar. Profesionalisme dapat diwujudkan dalam berbagai hal. Salah satu caranya adalah dengan mengikuti pelatihan-pelatihan terkait pengembangan kualitas kemampuannya. Materi pelatihan terkait penelitian-penelitian bagi guru sangat penting dan mutlak perlu dilakukan. Selain Penelitian Tindakan Kelas (PTK) yang sudah sering dilakukan guru, Penelitian dan Pengembangan juga penting untuk meningkatkan kinerja guru dalam bidan pedagogik dan profesionalisme. Dengan metode Penelitian dan Pengembangan atau Research and Development (RnD), guru akan dapat mengevaluasi kinerjanya dalam proses belajar mengajar di kelas, guru juga dapat menghasilkan sebuah produk untuk mempermudah siswa dalam memahami materi yang disampaikan oleh guru. Dengan melakukan evaluasi terhadap kinerja guru dalam proses belajar mengajar di kelas, maka diharapkan akan terjadi peningkatan kualitas pembelajaran di kelas dan pada giliran selanjutnya sekolah.
\end{abstract}

Kata Kunci: Penelitian R\&D, Guru Sekolah Dasar

\begin{abstract}
Professional competence is related to the ability of teachers to master material from fields of study or subjects under their broad and in-depth authority. Professional competence also includes mastery of scientific material, mastery of curriculum and syllabus, specific methods of learning in the field of study, and ethical insight and professional development. Personality and social competencies are closely related to the ability of teachers to interact and communicate effectively and efficiently, both with students, fellow teachers, parents/guardians of students, and the surrounding community. Professionalism can be manifested in various ways. One way is by taking part in training related to the development of the quality of his abilities. Training material related to research for teachers is very important and needs to be done. In addition to Classroom Action Research (CAR) which teachers have often done, Research and Development are also important to improve teacher performance in pedagogic midwives and professionalism. With the Research and Development (RnD) method, teachers will be able to evaluate their performance in the teaching and learning process in class, the teacher can also produce a product to make it easier for students to understand the material presented by the teacher. By evaluating the performance of teachers in the teaching and learning process in the classroom, it is hoped that there will be an increase in the quality of learning in the classroom and the next school turn.
\end{abstract}

Keywords: R \& D Research, Elementary School Teachers 


\section{PENDAHULUAN}

Mengacu pada UU Guru dan Dosen No. 14 tahun 2005, Guru sebagai tenaga pendidik sekaligus sebagai pengajar dituntut memiliki empat jenis kompetensi, yaitu: kompetensi kepribadian, kompetensi pedagogik, kompetensi profesional, dan kompetensi sosial. Kompetensi kepribadian berkaitan dengan kepribadian guru yang harus mantap, dewasa, tidak mudah emosional, beriman dan bertaqwa kepada Tuhan yang Maha Esa, arif, berwibawa, serta dapat menjadi teladan bagi anak didiknya. Kompetensi pedagogik berkenaan dengan kemampuan guru dalam proses belajar mengajar di kelas. Guru harus mampu merencanakan, melaksanakan, dan menilai seluruh proses pembelajaran yang dilakukannya, termasuk di dalamnya keterampilan menggunakan media dan menguasai berbagai metode pembelajaran. Dengan kata lain, kompetensi pedagogik mempersyaratkan guru untuk menguasai ilmu pendidikan.

Keempat jenis kompetensi guru tersebut memang disyaratkan bagi guru, khususnya yang telah memiliki sertifikat sebagai pendidik, baik melalui pengajuan dan penilaian portofolio, pelatihan PLPG maupun bagi guru yang telah mengikuti pendidikan profesi guru (PPG). Guna menunjang pencapaian sertifikat sebagai pendidik itu, maka guru harus dapat terus mengembangkan kemampuannya. Salah satu caranya adalah dengan mengikuti pelatihan-pelatihan terkait pengembangan kualitas kemampuannya. Materi pelatihan terkait penelitian-penelitian bagi guru sangat penting dan mutlak perlu dilakukan. Selain Penelitian Tindakan Kelas (PTK) yang sudah sering dilakukan guru, Penelitian dan Pengembangan juga penting untuk meningkatkan kinerja guru dalam bidan pedagogik dan profesionalisme. etode Penelitian dan Pengembangan atau akrab dengan istilah Research and Development $(R n D)$, diharapkan selain guru akan dapat mengevaluasi kinerjanya dalam proses belajar mengajar di kelas, guru juga dapat menghasilkan sebuah produk untuk mempermudah siswa dalam memahami materi yang disampaikan oleh guru. Dengan melakukan evaluasi terhadap kinerja guru dalam proses belajar mengajar di kelas, maka diharapkan akan terjadi peningkatan kualitas pembelajaran di kelas dan pada giliran selanjutnya sekolah.

Kompetensi profesional terkait dengan kemampuan guru dalam menguasai materi dari bidang studi atau mata pelajaran yang menjadi kewenangannya secara luas dan mendalam. Kompetensi profesional juga mencakup penguasaan materi keilmuan, penguasaan kurikulum dan silabus, metode khusus pembelajaran bidang studi, dan wawasan etika serta pengembangan profesi. Sementara kompetensi sosial sangat erat berhubungan dengan kemampuan guru dalam berinteraksi dan berkomunikasi secara efektif dan efisien, baik dengan peserta didik, sesama guru, orang tua / wali peserta didik, dan masyarakat sekitar (Siswoyo, et al., 2008: 122).

Analisis situasi di atas, permasalahan yang dihadapi SD Negeri 1 Arcawinangun adalah sebagian besar guru masih kesulitan dalam melakukan penelitian pengembangan yang dilakukan di sekolah, karena guru apabila melakukan pengembangan baik tentang bahan ajar maupun media bisa digunakan untuk menambah ilmu serta untuk mengatasi segala keterbatasan yang berkaitan dengan pembelajaran. Hasil diskusi dengan Kepala SD Negeri 1 Arcawinangun menyimpulkan bahwa permasalahan yang paling krusial untuk segera ditangani adalah pelatihan tentang penelitian pengembangan atau $R \& D$ untuk memberikan kesempatan kepada guru dalam mengembangkan bahan ajar ataupun media pembelajaran.

\section{METODE}

Metode pendekatan yang digunakan untuk realisasi kegiatan ini dengan program kemitraan antara Prodi PGSD FKIP UMP dengan SD Negeri 1 Arcawinangun. Program kemitraan ini sebagai perwujudan pelaksanaan Tri Dharma Perguruan Tinggi khususnya bidang pengabdian pada masyarakat yang berupa pelatihan penelitian R\&D Recearch and Development Bagi Guru SD Negeri 1 Arcawinangun. Program kemitraan ini dimulai dari MoU antara SD Negeri 1 Arcawinangun dengan FKIP UMP. Jika diukur dari empat kompetensi tersebut, maka dengan pelatihan R\&D bagi guru akan dapat mengembangkan kompetensi pedagogik dan kompetensi profesionalnya. Kinerja guru dalam profesinya sebagai pendidik akan dapat ditingkatkan dan dikembangkan jika guru memiliki kemampuan dalam melakukan penelitian. Pelatihan dilaksanakan di SDN 1 Arcawinangun Kecamatan Purwokerto Timur Kabupaten Banyumas pada hari Kamis, 18 Februari 2016. Metode yang digunakan dalam kegiatan ini adalah pemaparan materi oleh dua dosen menggunakan metode ceramah bervariasi 
dengan powerpoint dan video pembelajaran, lalu diskusi. Kegiatan diakhiri dengan penarikan kesimpulan dari meteri pelatihan.

\section{HASIL DAN PEMBAHASAN}

Setelah melaksanakan kegiatan pelatihan metodologi Penelitian dan Pengembangan, maka dapat disampaikan hasil evaluasi kegiatan sebagai berikut:

1. Dari seluruh peserta yang mengikuti pelatihan mitigasi bencana menunjukkan bahwa seluruh guru (17 guru) belum pernah mendapatkan atau mengikuti pelatihan metodologi Penelitian dan Pengembangan di lingkungan sekolah maupun di luar sekolah,

2. Seluruh peserta menyatakan bahwa mereka memahami materi metodologi Penelitian dan Pengembangan yang diberikan serta metode yang digunakan dalam pelatihan sangat menyenangkan, selain itu pelatihan semacam ini sangat penting dan bermanfaat.

Kegiatan pelatihan ini telah dilksanakan dengan baik dan mendapat tanggapan yang sangat baik. Para guru sangat mendukung kegiatan pelatihan metodologi Peneltian dan Pengembangan ini. Saran dari beberapa guru yaitu agar pelatihan ini dilaksanakan dengan cakupan waktu yang lebih luas lagi. Pelaksanaan kegiatan pelatihan metodologi Penelitian dan Pengembangan ini dilaksanakan melalui skenario pembelajaran bagi guru. Adapun skenario pelaksanaan pelatihan ini dapat digambarkan dalam alur kerja sebagai berikut.

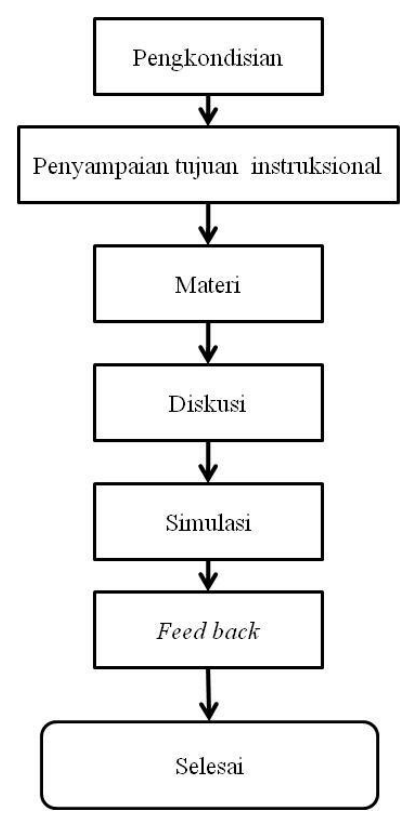

Gambar. Alur kerja pelaksanaan pelatihan

Metodologi Penelitian dan Pengembangan

\section{Luaran yang Diperoleh}

Target luaran program pelatihan yang diperoleh adalah:

1. Pengetahuan dan informasi tentang metodologi Peneltian dan Pengembangan (Research and Development). Sasaran pelatihan ini yaitu para guru, kepala SD N 1 Arcawinangun.

2. Penyusunan proposal Penelitian dan Pengembangan yang dibuat oleh guru peserta pelatihan.

\section{Faktor Pendorong dan Penghambat}

\section{Faktor Pendorong}

a. Kepala sekolah dan para guru sangat terbuka dengan kegiatan yang dilakukan sehingga tim dapat melaksanakan IbM dengan baik.

b. Kerjasama tim yang baik dan saling mendukung dari tim dosen dan juga mahasiswa sehigga kegiatan ini dapat terlaksana dengan baik.

2. Faktor penghambat 
Pelaksanaan pengabdian ini sedikit terkendala karena waktu, Pelaksanaan juga terkendala ketika bulan Januari disibukkan dengan pelaksaaan UAS dan pelatihan.

\section{SIMPULAN}

Profesionisme guru sangat penting dalam proses pembelajaran di dalam kelas ataupun di luar kelas. Salah satu wujud profesionalisme guru adalah senantiasa meningkatkan kemampuan dengan pengembangan diri. Penelitian dan pengembangan sebagai sebuah metode diharapkan menjadi satu dari sekian banyak metodologi yang dapat guru laksanakan untuk pengembangan dirinya. Pengetahuan peserta setelah diberi materi Pelatihan Metodologi Penelitian dan Pengembangan meningkat. Peserta dapat menyusun Proposal Penelitian dan Pengembangan dengan langkah-langkah yang benar.

\section{SARAN}

Beberapa saran dapat disampaikan sebagai berikut: Sesuai dengan Undang-Undang Guru dan Dosen bahwa guru adalah jabatan profesi, untuk itu guru dituntut meningkatkan kualitas pembelajaran di kelas. Dengan melaksanakan evaluasi pembelajaran dengan baik dan benar, diharapkan guru dapat meningkatkan tugas profesinya. Program Studi PGSD FKIP UMP lebih banyak lagi melibatkan mahasiswa dalam pengabdian pada masyarakat sehingga memberi pengalaman mahasiswa dalam pelaksanaan Tri Dharma Perguruan Tinggi

\section{UCAPAN TERIMA KASIH}

Penulis mengucapkan terima kasih kepada Lembaga Penelitian dan pengabdian masyarakat Universitas Muhammadiyah Purwokerto yang telah memberi dukungan financial terhadap pengabdian ini.

\section{DAFTAR PUSTAKA}

Admin Google. (2016), Google Form. Diambil kembali dari Google Form: https://www. Google.com/intl/id/forms/about/

Admin, Welcome to Google Form, Dikutip kembali dari https://www.Google.com/ intl/id/forms/about/ pada 10 Februari 2021.

Anonim. 2006. Rencana Strategik Majelis Pendidikan Dasar dan Menengah Pimpinan Daerah Muhammadiyah Banyumas Masa Bakti 2005 - 2010. Purwokerto: Majelis Dikdasmen PDM Banyumas. Tidak diterbitkan.

Arikunto, S. 2010. Prosedur Penelitian: Suatu Pendekatan Praktek. Jakarta: Rineka Cipta.

Borg, W.R. \& Gall, M. 2003. Educational Research, an Introduction. New York: Longman.

Creswell, John W. 2009. Research Design, Qualitative, Quantitative, and Mixed Methods Approaches. Los Angeles: Sage.

Pamujo. 2009. "Peningkatan Motivasi Belajar Siswa Pada Pelajaran Sejarah Melalui Pembelajaran Kooperatif Tipe STAD di Madrasah Tsanawiyah (MTs) Muhammadiyah Purwokerto," dalam Khazanah Pendidikan, Jurnal Ilmiah Kependidikan. Volume I, Nomor 2, Maret. Purwokerto: FKIP Universitas Muhammadiyah Purwokerto.

Putra, N. 2013. Research \& Development Penelitian dan Pengembangan: Suatu Pengantar. Jakarta: Rajawali Pers.

Siswoyo, Dwi, et al. 2008. Ilmu Pendidikan. Yogyakarta: UNY Press.

Sugiyono. 2015. Metode Penelitian dan Pengembangan (Research and Development/ R\&D). Bandung: Alfabeta

Suwarno dan Kartono. 2007. "Pengembangan Kemampuan Siswa Meneliti Sejarah Lokal Melalui Model Inkuiri," dalam Cakrawala Pendidikan, Jurnal Ilmiah Pendidikan. Tahun XXVI, Nomor 3. Yogyakarta: LPM Universitas Negeri Yogyakarta.

Trianto. 2009. Mendesain Model Pembelajaran Inovatif Progresif. Jakarta: Kencana Prenada Group. Wiriaatmadja, Rochiati. 2006. Metode Penelitian Tindakan Kelas Untuk Meningkatkan Kinerja Guru dan Dosen. Cetakan II. Bandung: PT Remaja Rosda Karya. 